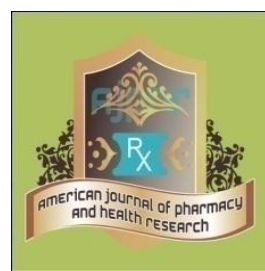

Research Article
AMERICAN JOURNAL OF PHARMACY AND HEALTH RESEARCH

www.ajphr.com

2018, Volume 6, Issue 12

ISSN: 2321-3647(online)

\title{
Pharmacological Evaluation of Ethanolic Extract of Leaves of Memecylon Kollimalayanum
}

\author{
G.Sekar $^{1}$, T.Venkatachalam ${ }^{2}$, P.Kalaisevi ${ }^{3}$, and R.Ramprasad ${ }^{4}$ \\ 1.S S M College of Pharmacy Chinniampalayam Pudur, Tamil Nadu 638312 \\ 2,3.Annai JKK Sampoorani Ammal College of Pharmacy Ethirmedu, Valayakaranoor Post, \\ Komarapalayam, Namakkal, Tamil Nadu 638183 \\ 4.Arulmigu Kalasa Lingam College of Pharmacy, Anand Nagar Krishnankoil-626126
}

\begin{abstract}
The present studies emphasize the investigation on ethanolic extract of Memecylon kollimalayanum. (Family- Melastomataceae) leaves for its anti-diabetic activity in animal model. Alloxan induced diabetes model was used for the study. The pharmacological and acute toxicity studies of ethanolic extract was performed by following, OECD-423 guidelines (Acute toxic class method). No mortality or acute toxicity was observed upto $2000 \mathrm{mg} / \mathrm{kg}$ of body weight. The standardized doses of 250,500, 1000 and $2500 \mathrm{mg} / \mathrm{kg} 1$ body weight of the extract were administered orally to normal and diabetic rats in order to define its hypo-glycemic potential. Results The Biological dose of extract Memecylon kollimalayanum dose was selected 200mg/kg and $400 \mathrm{mg} / \mathrm{kg}$ in this dose possessed significant antidiabetic activity. This study shows that flavanoids present in this extract may be possibly responsible for the antidiabetic activities respectively. Histopathological studies on isolated pancreas revealed that ethanolic extract of Memecylon kollimalayanum reversed the changes which produced due to diabetes caused by Alloxan. The normal pattern of histology of pancreas was observed.
\end{abstract}

Keywords: Ethanolic Extract, OECD-423 guidelines

*Corresponding Author Email: rramprasad75@gmail.com

Received 10 September 2018, Accepted October 2018

Please cite this article as: Ramprasad R. et al., Pharmacological Evaluation of Ethanolic Extract of Leaves of Memecylon Kollimalayanum. American Journal of Pharmacy \& Health Research 2018. 


\section{INTRODUCTION}

Diabetes mellitus is a metabolic disorder characterized by high blood sugar levels that results from either an inherited or acquired deficiency in the production of insulin by the pancreatic islet cells of Langerhans or by the ineffectiveness of the insulin produced at the peripheral tissues [1]. Diabetes mellitus is a chronic medical condition which though can be controlled lasts a lifetime [2]. The chronic hyper glycemia of diabetes is associated with long-term damage, dysfunction, and failure of various organs, especially the eyes, kidneys, nerves, heart, and blood vessels [3]. An estimated 171 million people were suffering from diabetes in 2000, and this number could total 366 million by 2030 [4]. In 2012, 1.5 million deaths were reported to be directly caused by diabetes [5]. Traditional medicine appears to offer gentler means of managing DM when allopathic medicines fail to work, or to patients who cannot afford them [6,7]. Due to inadequate knowledge of the contents of medicinal plants, herbal medicines are not often regulated, lack of information on the pharmacological toxicity of their compounds is also a major concern [8]. Leaves 2.5-5 $\mathrm{x}$ 1.5-3 cm, ovate-oblong or elliptic, base cuneate, apex obtuse to rounded, coriaceous, green colour, drying yellowish green having a pungent smell. pharmacological studies have been carried out on the leaves of Hence, I have decided to choose the Memecylon kollimalayanum project on Which Memecylon kollimalayanum includes detailed studies on Preliminary Phytochemical and Pharmacological activities of Oral glucose tolerance, and In-vivo Anti- diabetic studies [9].

\section{MATERIALS AND METHOD}

\section{Collection of specimen and identification}

The species for the proposed study that is leaves of collected Memecylon kollimalayanum carefully from the Kollimalai hills, Namakkal Dt, Tamilnadu. The plant was positively identified by Dr. Ratheesh narayanan Asst. Professor department of botany, PAYYANUR college, Payyanur. The plant was authenticated as o Memecylon kollimalayanum family Melastomatacae from available literature. The Memecylon Kollimalyanum leaves were subjected to shade drying to treat fungus until complete dryness of leaves. Then the dried leaves were powdered by mixer grinder until to get coarse powder, which was used for further detailed studies, extraction with solvent and phytochemical studies[10].

\section{PHARMACOGNOSTICAL STUDIES}

Ash value: (Kokate et al., 1985)

Ash values are helpful in determining the quality and purity of crude drug, especially in the powdered form. 


\section{LOSS ON DRYING:}

About $1.5 \mathrm{gm}$ of powdered drug was weighed accurately in a tarred porcelain dish which was previously dried at $105^{\circ} \mathrm{C}$ in hot air oven to constant weight and then weighed. From the difference in weight, the percentage loss of drying with reference to the air dried substance was calculated [11].

\section{EXTRACTIVE VALUES}

$5 \mathrm{gm}$ of the air-dried coarse powder of the Leaves bodies of Memecylon kollimalayanum was macerated with $100 \mathrm{ml}$ of $90 \%$ ethanol in a closed flask for 24 hours, shaking frequently during the first 6 hours and allowing standing for 18 hours. Thereafter, it was filtered rapidly taking precautions against the loss of the solvent. Out of that filtrate, $25 \mathrm{ml}$ of the filtrate was evaporated to dryness in a tarred flat bottomed shallow dish, dried at $105^{\circ} \mathrm{C}$ and weighed. The percentage of ethanol soluble extractive value was calculated with reference to the air-dried drug. The results are recorded in the table [12].

\section{Determination of water soluble extractive value:}

Weigh accurately $5 \mathrm{gm}$ of coarsely powdered drug and macerate it with $100 \mathrm{ml}$ of chloroform water in closed flak for 24 hours, shaking frequently during the first 6 hours and allow to standing for 18 hours. Thereafter, it was filtered rapidly taking precautions against loss of the solvent. Then $25 \mathrm{ml}$ of the filtrate was evaporated to dryness in a tarred flat bottomed shallow dish, dried at $105^{\circ} \mathrm{C}$ and weighed. The percentage of water soluble extractive was calculated with reference to the air dried drug [13].

\section{Extraction of Memecylon kollimalayanum leaves:}

\section{Ethanol extract:}

About 250gm of air dried powdered material was taken in $3000 \mathrm{ml}$ soxhlet apparatus and extracted with petroleum ether for 7 days. At the end of 7 th day the powder was taken out and dried. After drying it was again packed and extracted by using ethanol (S.D. Fine Chemicals Ltd. Mumbai, India) as solvent, till colour disappeared. The temperature was maintained at $55^{\circ} \mathrm{C}-65^{\circ} \mathrm{C}$. After that extract was concentrated by distillation and solvent was recovered. The final solution was evaporated to dryness. The colour, consistency and yield of ethanolic extract were noted [14].

\section{Acute Oral Toxicity Study:}

Twelve animals Albino mice, (25-30gm) were selected for studies. The starting dose of ethanolic extracts of Memecylon kollimalayanum $1300 \mathrm{mg} / \mathrm{kg}$, b.w, p.o, was administered. Most of the crude extracts possess LD50, value more than $2000 \mathrm{mg} / \mathrm{kg}$ of the body weight of the animal used. Dose volume was administered $0.1 \mathrm{ml} / 100 \mathrm{gm}$ body weight to the animal by oral route. After giving the 
dose toxic signs were observed within 3-4 hours. Body weight of the animals before and after administration, onset of toxicity and signs of toxicity like changes in the skin and fur, eyes and mucous membrane and also respiratory, circulatory, autonomic and central nervous systems and somatomotors activity and behaviour pattern, sign of tremors, convulsion, salivation, diarrhoea, lethargy and sleep and coma was also to be noted, if any, was observed. The animal toxic or death was observed up to 14 days [15].

\section{ORAL GLUCOSE TOLERANCE TEST (OGTT)}

The overnight fasted (18hr) normal rats were taken and divided into four groups consists of six animals. They were provided with drinking water only. Normal saline solution was administered to group I animals. Group II animals were received Glibenclamide (3mg/kg,b.w) as a standard. Memecylon kollimalayanum ethanol extract (200 and $400 \mathrm{mg} / \mathrm{kg}$ ) was administered by oral route to group III and IV Glucose $(2 \mathrm{mg} / \mathrm{kg})$ load was fed 30 minutes after the administration of extracts. Blood was withdrawn from tail vein under mild ether anesthesia initial, 30,60 and 90 minutes after glucose administration (V.Babu et al., 2003) and glucose level were estimated using glucose strips and a glucometer (Standard diagnostics Ltd). Blood glucose levels were noted and reported[16].

\section{EVALUATION OF ANTI-DIABETIC ACTIVITY}

Female albino- Wistar rats weighing 150-250g were used in the present study. All rats were kept at room temperature of $22-25^{\circ} \mathrm{c}$ in the animal house. All the animals were followed the internationally accepted ethical guidelines for the care of laboratory animals. Prior to the experiments, rats were fed with standard food for one week in order to adapt to the laboratory conditions in accordance with the recommendations for the proper care and use of laboratory animals [17].

\section{Experimental Design:}

Experimental rats were divided into 5 groups of six animals each all the group of animals were induced diabetic except control and treated for 21days as follows.

Group I: Normal control rats fed with vehicles only. (Normal saline with 1\%CMC)

Group II: Diabetic controls rats (Alloxan monohydrate $120 \mathrm{mg} / \mathrm{kg}$ body weight of rats, once i.p injection).

Group III: Diabetic rats treated with standard drug, Glibenclamide 3mg/kg per oral body weight.

Group IV: Diabetic rats treated with ethanolic extract of Memecylon kollimalayanum (M.B.Viswan) $200 \mathrm{mg} / \mathrm{kg}$, per oral, dissolved in $1 \%$ carboxy methyl cellulose (CMC).

Group V: Diabetic rats treated with ethanolic extract of Memecylon kollimalayanum 400mg/kg, per oral, dissolved in $1 \%$ carboxy methyl cellulose (CMC). 


\section{Biochemical Assays}

Tissue homogenate were prepared with $0.025 \mathrm{M}$ Tris - Hcl buffer ( $\mathrm{pH} 7.5$ ) from the organs like liver, kidney and pancreas which were removed on the 21st day. After centrifugation at 10,000 rpm for 10 minutes, the clear supernatant was used to measure antioxidant activity.

\section{Estimation of blood glucose level:}

Estimation of plasma blood glucose levels is carried out using the standard glucose estimation kit

\section{Lipid Profile:}

Test Leaf extract, Metformin and the combination of (leaf extract \& Metformin) were administered daily for four weeks in the alloxan-induced diabetic rats. After completing drug treatment for 28 days serum was collected and the concentration of TC, TG, LDL and HDL Cholesterol were measured by taking absorbance by UV spectrophotometer using diagnostic kits (LINEAR CHEMICALS, Spain). The ratio of LDL to HDL cholesterol was calculated[18,19,20,21].

\section{Statistical analysis}

Values are expressed as mean \pm standard deviation for six animals in one groups. The results are estimated by one way analysis of difference (ANOVA) followed by post hoc Dunnett's multiple relationship test. Differences involving means were considered to be statistically considerable at $(\mathrm{p} \leq$ 0.05) (Festing et al., 2006).

\section{RESULTS AND DISCUSSION}

Table 1: Data for ash values for powdered leaves of Memecylon kollimalayanum

\begin{tabular}{ll}
\hline Ashes & Ash values $(\%$ w/w $)$ \\
\hline Total ash 9.2 \\
Acid insoluble ash 2.9 \\
Water soluble ash 3.2 \\
\hline
\end{tabular}

Ashes Ash values(\%w/w)

Total ash $\quad 9.2$

Acid insoluble ash $\quad 2.9$

Water soluble ash $\quad 3.2$

Extractive values and Loss on drying

Table 2: Data for extractive values and loss on drying for powered leaves of Memecylon kollimalayanum

\begin{tabular}{ll}
\hline Analytical parameters & Percentage $(\%$ w/w) \\
\hline Water soluble extractive & 11.2 \\
Alcohol soluble extractive 3.3 \\
Loss on drying & 4 \\
\hline
\end{tabular}


Analytical parameters Percentage(\%w/w)

Water soluble extractive $\quad 11.2$

Alcohol soluble extractive $\quad 3.3$

Loss on drying $\quad 4$

The analytical parameters were investigated and reported as, total Ash value $(9.2 \% \mathrm{w} / \mathrm{w})$, acid insoluble ash value $(2.9 \% \mathrm{w} / \mathrm{w})$, water soluble ash value $(3.2 \% \mathrm{w} / \mathrm{w})$, water soluble extractive (11.2), alcohol soluble extractive(3.3) and loss on drying (4\%w/w). The above studies were enabled to identify the plant material for further investigation and from an important aspect of drug studies. The results were given in Table 1, 2 .

\section{Acute Oral Toxicity Study:}

The acute oral toxicity of the ethanolic extract of Memecylon kollimalayanum was carried out as per OECD 423-guidelines (Acute toxic class method). Acute toxicity studies revealed that LD50>2000mg/kg for the extract. Hence, the biological dose was fixed at EEMK 200mg and $400 \mathrm{mg}$ of body weight for the extract.

\section{EFFECT ON GLUCOSE TOLERANCE}

In OGTT, the doses of EEMK $200 \mathrm{mg} / \mathrm{kg}$ and $400 \mathrm{mg} / \mathrm{kg}$ increased the tolerance for glucose suggesting increased peripheral utilization of glucose. The reduction in blood glucose level was dose dependent. The results were given in Table.: 3

Table 3: Effect of ethanolic extract of Memecylon kollimalayanum and Glibenclamide on glucose tolerance of diabetic rats.

\begin{tabular}{|c|c|c|c|c|c|}
\hline \multirow[t]{2}{*}{ Groups } & \multirow[t]{2}{*}{ Treatment } & \multicolumn{4}{|c|}{ Change in blood glucose levels(mg/dL) } \\
\hline & & Fasting & $\begin{array}{l}\text { After } 30 \\
\text { Minutes }\end{array}$ & $\begin{array}{l}\text { After } 60 \\
\text { minutes }\end{array}$ & $\begin{array}{l}\text { After } 90 \\
\text { minutes }\end{array}$ \\
\hline I. & Glucose $2 \mathrm{mg} / \mathrm{kg}$ & $85.35 \pm 3.80$ & $126 \pm 3.01$ & $128.32 \pm 2.20$ & $109.4 \pm 3.66$ \\
\hline II. & Glibenclamide $3 \mathrm{mg} / \mathrm{kg}$ & $67.65 \pm 4.33$ & $82.32 \pm 2.58^{\mathrm{a}}$ & $61.84 \pm 2.47^{\mathrm{a}}$ & $50.6 \pm 4.40^{\mathrm{a}}$ \\
\hline III. & EEMK 200mg/kg & $66.83 \pm 1.52$ & $112.67 \pm 6.28^{\mathrm{a}}$ & $114.33 \pm 12.00^{\mathrm{a}}$ & $94.67 \pm 6.89^{\mathrm{a}}$ \\
\hline IV. & EEMK 400mg/kg & $79 \pm 3.18$ & $100 \pm 2.41^{c}$ & $106.15 \pm 8.91 \mathrm{~b}$ & $91.65 \pm 3.95^{\mathrm{a}}$ \\
\hline
\end{tabular}

Values are given as mean \pm S.E.M for groups of six animals each. Values are statistically significant at $\mathrm{a}=* * *=\mathrm{p}<0.001 ; \mathrm{b}=* *=\mathrm{p}<0.01 ; \mathrm{c}=*=\mathrm{p}<0.05$.EEMK. (Analyzed by one-way analysis of variance (ANOVA) followed by Tukey-Kramer multiple comparison tests). Normal control group I was compared with extract treated groups III and IV. Values are given as mean \pm S.E.M for groups of six animals each. Values are statistically significant at $a=* * *=p<0.001 ; b=* *$ $=\mathrm{p}<0.01 ; \mathrm{c}=^{*}=\mathrm{p}<0.05$.EEMK. (Analyzed by one-way analysis of variance (ANOVA) followed 
by Tukey-Kramer multiple comparison tests). Extract treated group III, IV were compared with group I (Normal) and Group II (Standard).

Values are given as mean \pm S.E.M for groups of six animals each. Values are statistically significant at $\mathrm{a}=* * *=\mathrm{p}<0.001 ; \mathrm{b}=* *=\mathrm{p}<0.01 ; \mathrm{c}=*=\mathrm{p}<0.05$. (Analyzed by one-way analysis of variance (ANOVA) followed by Tukey-Kramer multiple comparison tests). While, significant $(\mathrm{p}<0.01, \mathrm{p}<0.001)$ increase in body weight was observed in rats treated with ethanolic extract of Memecylon kollimalayanum. The EEMK treated diabetic rats $(400 \mathrm{mg} / \mathrm{kg})$ were slightly increased the body weight level and showed in Table: 4

Table 4: Body weight changes in ethanolic extract of Memecylon kollimalayanum and Glibenclamide on control and experimental groups of rats

\begin{tabular}{lllc}
\hline Group & Treatment & \multicolumn{2}{l}{ Body weight changes (g) } \\
\cline { 3 - 4 } & & Day 0 & Day 21 \\
\hline I & Normal control rats (vehicles only) & $145 \pm 7.67$ & $204.15 \pm 11.94$ \\
II & Diabetic control rats & $162.5 \pm 8.54$ & $129.18 \pm 7.67^{\mathrm{b}}$ \\
III & Diabetic group + Glibenclamide & $150 \pm 6.44^{\mathrm{a}}$ & $208.37 \pm 12.37^{\mathrm{a}}$ \\
& 3mg/kg & & \\
IV & Diabetic group + EEMK (200/kg) & $154.17 \pm 7.67^{\mathrm{b}}$ & $200 \pm 6.46^{\mathrm{b}}$ \\
V & Diabetic group + EEMK (400mg/kg) & $162.6 \pm 14.05^{\mathrm{c}}$ & $187.6 \pm 17.98^{\mathrm{c}}$ \\
\hline
\end{tabular}

Values are given as mean \pm S.E.M for groups of six animals each. Values are statistically significant at $\mathrm{a}=* * *=\mathrm{p}<0.001 ; \mathrm{b}=* *=\mathrm{p}<0.01 ; \mathrm{c}=*=\mathrm{p}<0.05$. (Analyzed by one-way analysis of variance (ANOVA) followed by Tukey-Kramer multiple comparison tests). While, significant $(\mathrm{p}<0.01, \mathrm{p}<0.001)$ increase in body weight was observed in rats treated with ethanolic extract of Memecylon kollimalayanum The EEMK treated diabetic rats $(400 \mathrm{mg} / \mathrm{kg})$ were slightly increased the body weight level and showed in Table:4

Table 5. Effect of Memecylon kollimalayanum ethanolic extract of and Glibenclamide on blood glucose level

\begin{tabular}{llllll}
\hline GroupTreatment & \multicolumn{4}{l}{ Blood glucose level (mg/dL) } & \\
\cline { 3 - 6 } & & Day 0 & Day 7 & Day 14 & Day 21 \\
\hline I & Normal control rats & $70.65 \pm 1.42$ & $80 \pm 2.34$ & $78.83 \pm 2.36$ & $72.33 \pm 1.82$ \\
II & Diabetic control rats & $380.6 \pm 13.57^{\mathrm{a}}$ & $336.84 \pm 7.18^{\mathrm{a}}$ & $354.84 \pm 10.81^{\mathrm{a}}$ & $369.32 \pm 12.91^{\mathrm{a}}$ \\
$\mathrm{III}$ & $\begin{array}{l}\text { Diabetic } \\
\text { group+Glibenclamide }\end{array}$ & $313.6 \pm 9.09^{\mathrm{a}}$ & $281.34 \pm 9.56^{\mathrm{a}} 233.65 \pm 5.42$ & $147.67 \pm 8.05^{\mathrm{a}}$ \\
VI & $\begin{array}{l}\text { Diabetic group + } \\
\text { EEMK (200mg/kg) }\end{array}$ & $334.66 \pm 8.90 \mathrm{c}$ & $285 \pm 13.26^{\mathrm{a}}$ & $174.82 \pm 8.91 \mathrm{a}$ & $161 \pm 10.81^{\mathrm{a}}$ \\
$\mathrm{V}$ & $\begin{array}{l}\text { Diabetic group + } \\
\text { EEMK (400mg/kg) }\end{array}$ & $321.84 \pm 12.16^{\mathrm{b}}$ & $286 \pm 5.08^{\mathrm{b}}$ & $157.82 \pm 7.30^{\mathrm{a}}$ & $160.5 \pm 7.74^{\mathrm{a}}$ \\
\hline
\end{tabular}


Values are given as mean \pm S.E.M for groups of six animals each. Values are statistically significant at $a=* * *=p<0.05 ; b=* *=p<0.01 ; c=*=p<0.001$. (Analyzed by one-way analysis of variance (ANOVA) followed by Tukey-Kramer multiple comparison tests). Diabetic control group II was compared with Normal control group I and extract treated groups IV, V and Standard III compared with Diabetic control group II. Values are given as mean \pm S.E.M for groups of six animals each. Values are statistically significant at $\mathrm{a}=* * *=\mathrm{p}<0.001 ; \mathrm{b}=* *=\mathrm{p}<0.01 ; \mathrm{c}=*$ $=\mathrm{p}<0.05$. A significant increase in the level of blood glucose, was observed in diabetic control rats when compared to control rats. Administration of EEMK and Glibencla mide to diabetic rats significantly decreased the elevated level of blood glucose, near to control level. Showed Table 5

\section{Changes in lipid profile:}

Table: 6. Effect of ethanolic extract of Memecylon kollimalayanum and Glibenclamide in lipid profile

\begin{tabular}{|c|c|c|c|c|c|c|}
\hline \multirow{2}{*}{\multicolumn{2}{|c|}{ GroupTreatment }} & \multirow{3}{*}{$\begin{array}{l}\begin{array}{l}\text { Total } \\
\text { Cholesterol }\end{array} \\
109.82 \pm 0.47\end{array}$} & \multicolumn{2}{|c|}{ Triglycerides LDL } & \multirow{2}{*}{\multicolumn{2}{|c|}{$\begin{array}{l}\text { VLDL } \quad \text { HDL } \\
\text { Cholesterol Cholesterol }\end{array}$}} \\
\hline & & & (mg/dl) & Cholesterol & & \\
\hline $\mathrm{I}$ & $\begin{array}{l}\text { Normal control group } \\
\text { (vehicles only) }\end{array}$ & & $91.16 \pm 1.71$ & $49.92 \pm 1.19$ & $18.24 \pm 0.34$ & $41.65 \pm 0.87$ \\
\hline II & Diabetic control rats & $212.82 \pm 1.84^{\mathrm{a}}$ & $184 \pm 2.63^{\mathrm{a}}$ & $155.4 \pm 2.15$ & $36.7 \pm 0.52^{\mathrm{a}}$ & $21 \pm 1.06^{\mathrm{a}}$ \\
\hline III & $\begin{array}{l}\text { Diabetic group }+ \\
\text { glibenclamide }\end{array}$ & $122.17 \pm 1.94^{\mathrm{a}}$ & $132 \pm 2.63^{\mathrm{a}}$ & $\begin{array}{l}56.74 \pm 1.67 \\
\mathrm{a}\end{array}$ & $\begin{array}{l}26.52 \pm 0.52 \\
\mathrm{a}\end{array}$ & $\begin{array}{l}38.84 \pm 1.07 \\
\mathrm{a}\end{array}$ \\
\hline IV & $\begin{array}{l}\text { Diabetic group }+ \\
\text { EEMK }(200 \mathrm{mg} / \mathrm{kg})\end{array}$ & $134.6 \pm 2.11^{\mathrm{a}}$ & $62.83 \pm 1.45^{\mathrm{a}}$ & $83.1 \pm 2.80 \mathrm{~b}$ & $\mathrm{a}^{12.55 \pm 0.27}$ & $\begin{array}{l}38.82 \pm 1.07 \\
\mathrm{a}\end{array}$ \\
\hline V & $\begin{array}{l}\text { Diabetic group + } \\
\text { EEMK }(400 \mathrm{mg} / \mathrm{kg})\end{array}$ & $131.67 \pm 2.94^{b}$ & $80.83 \pm 2.11^{\mathrm{a}}$ & & $1617+0$ & $\begin{array}{l}31.84 \pm 0.82 \\
\mathrm{a}\end{array}$ \\
\hline
\end{tabular}

The serum lipid values of TC, TG of those were treated with EEMK extract returned to values near to control group. The level of cholesterol and triglyceride increased in diabetic animals when compared to control animals. The level of LDL and VLDL increased in diabetic animals when compared to control animals. After EEMK treatment, the higher level of both LDL, VLDL were increased to near control. The showed that treatment with EEMK significantly $(200 \mathrm{mg} / \mathrm{kg}$ and $400 \mathrm{mg} / \mathrm{kg}$ ) p<0.001 improved the lipid profile in Alloxan induced diabetic rats. Showed in Table.6.

Table 7 Effect of ethanolic extract of Memecylon kollimalayanum and Glibenclamide in Total protein, Albumin of control and experimental groups of rats

\begin{tabular}{llll}
\hline \multicolumn{2}{l}{ GroupTreatment } & \multicolumn{2}{c}{ Total proteinAlbumin } \\
& & $(\mathbf{m g} / \mathbf{d l})$ & $(\mathbf{m g} / \mathbf{d l})$ \\
\hline I & Normal control group (vehicles only) & $8 \pm 0.13$ & $3.867 \pm 0.10$ \\
II & Diabetic control rats & $5.44 \pm 0.19^{\mathrm{a}}$ & $1.77 \pm 0.11^{\mathrm{a}}$ \\
III & Diabetic group + glibenclamide (3mg/kg) $7.67 \pm 0.14 \mathrm{a}$ & $3.22 \pm 0.12^{\mathrm{a}}$ \\
\hline
\end{tabular}




\begin{tabular}{llll}
\hline IV & Diabetic group + EEMK (200mg/kg) & $7.3 \pm 0.13^{\mathrm{a}}$ & $3.08 \pm 0.09^{\mathrm{a}}$ \\
V & Diabetic group + EEMK (400mg/kg) & $8 \pm 0.18^{\mathrm{a}}$ & $3.26 \pm 0.08^{\mathrm{a}}$ \\
\hline
\end{tabular}

The plasma lipid values of Total protein and Albumin of those were treated with EEMK extract returned to values near to control group. The level of Total protein and Albumin in plasma of diabetic animals was increased. Total protein and Albumin where restored significantly near to normal in EEMK treated diabetic groups. Showed in Table No:7.

\section{HISTOPATHOLOGY OBSERVATION}

Examination of Pancreatic tissue of diabetic rats treated with Memecylon kollimalayanum indicated that pancreatic section appeared more (or) less like control.

\section{Group I: Normal control (Figure: 1)}

MICROSCOPY: Multiple section studied shows cells of pancreas with normal architecture and proportion. The acinar cells which stained strongly are arranged in lobules. The islet cells are embedded within acinar cells surrounded by thin fibrous capsule. No evidence of any inflammatory changes or malignancy.

IMPRESSION: Normal histology-Pancreas biopsy.

\section{Group II: Diabetic Control (Figure: 2)}

Multiple section studied shows pancreatic tissue with hyalinization of islets of langerhans cells with focal mild degenerative changes. Interstitium showing mild fibrosis, dilated, thick walled and congested blood vessels along with focal chronic inflammatory cell infiltrate.

IMPRESSION: Features shows strong pancreatic inflammation-Pancreas biopsy

\section{Group III: Diabetes group with Glibenclamide (Figure: 3)}

MICROSCOPY: Multiple section studied shows cells of pancreas with marked atrophy of pancreatic isle cells and minimal degenerative changes in acinar population. The within shows admixed eosinophilic material, pericapsular fibrosis, congested blood vessels and scattered mononuclear inflammatory cell in filteration surrounded by thin fibrous capsule. No evidence of any inflammatory changes or malignancy.

IMPRESSION: Features are that of insulinitis-Pancreas biopsy

\section{Group IV: Diabetes group with $200 \mathrm{mg} / \mathrm{kg}$ EEMK (Figure: 4)}

MICROSCOPY: Multiple section studied shows cells of pancreas with mild atrophy of pancreatic isle cells and minimal degenerative changes in acinar population. The acinar cells shows dark staining and are arranged in lobules. The islet cells are embedded within acinar cells which shows minimal pericapsular fibrosis, congested blood vessels and scattered mononuclear inflammatory 
cell infilteration surrounded by thin fibrous capsule. No evidence of any inflammatory changes or malignancy.

IMPRESSION: Features show mild decrease in pancreatic inflammation- Pancreas biopsy

\section{Group V: Diabetes group with $400 \mathrm{mg} / \mathrm{kg}$ EEMK (Figure: 5) MICROSCOPY:}

Multiple section studied shows cells of pancreas with mild atrophy of pancreatic isle cells and normal acinar population. The acinar cells shows dark staining and are arranged in lobules. The islet cells are embedded within acinar cells which shows minimal pericarp sular fibrosis, edema, congested blood vessels and very few scattered mononuclear inflammatory cell infilteration surrounded by thin fibrous capsule. No evidence of any inflammatory changes or malignancy.

IMPRESSION: Features show marked decrease in pancreatic inflammation-

Pancreas biopsy.

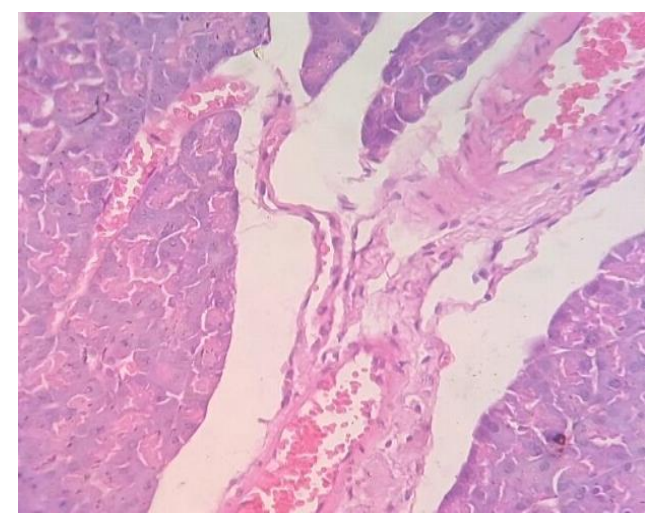

Figure: 1 (Normal control)

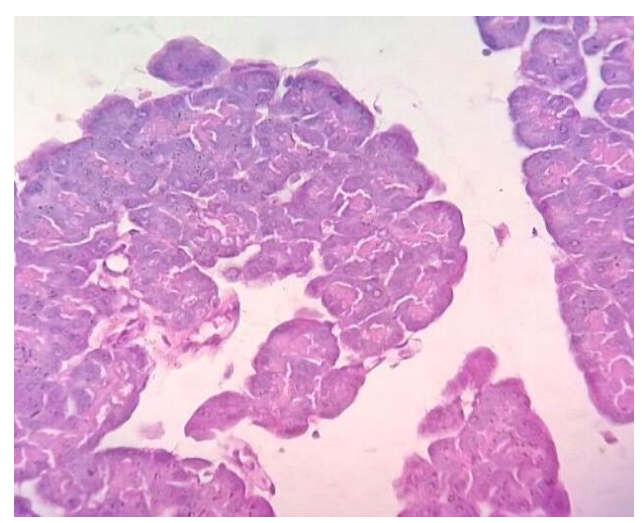

Figure: 2 (Diabetic control)

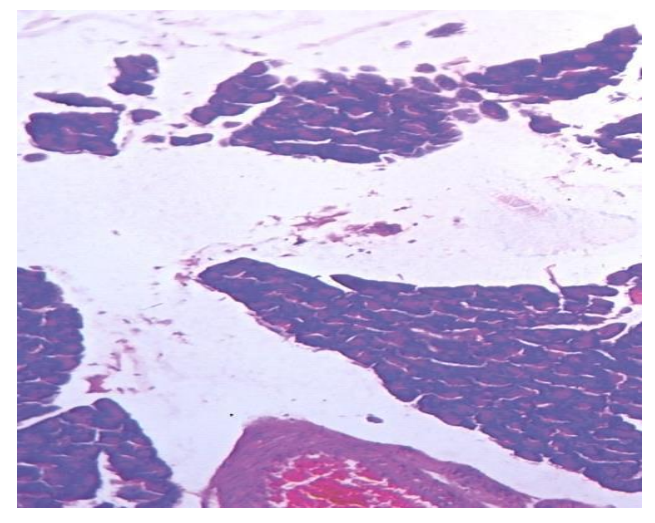

Figure: 3 (Diabetic group with glibenclamide) 


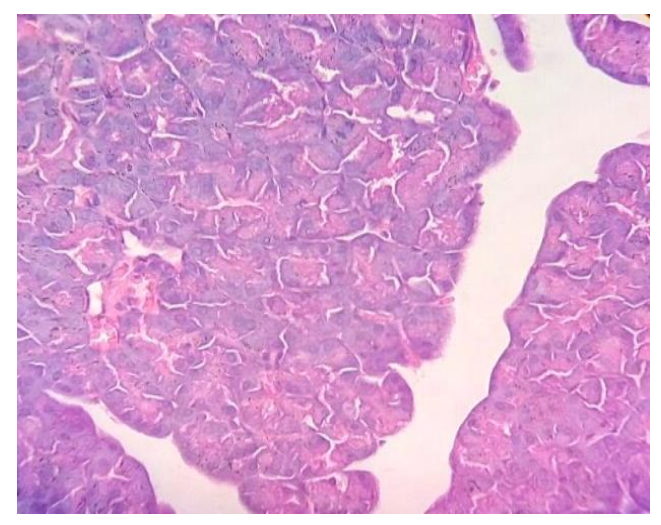

Figure 4 (Diabetic group with 200 mg EEMK)

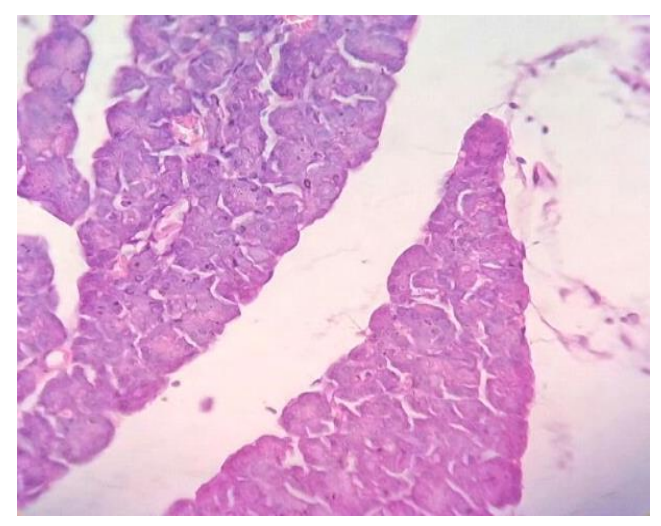

Figure 5: (Diabetic group with 400 mg EEMK)

\section{CONCLUSION}

The leaves of Memecylon kollimalayanum belonging to family Melastomataceae has been examined to gain an insight of its Phytochemical and pharmacological behaviors. The Pharmacognostical studies made on powdered Memecylon kollimalayanum like ash value, loss on drying gave valuable information. The pharmacological and acute toxicity studies of ethanolic extract was performed by following, OECD-423 guidelines (Acute toxic class method). No mortality or acute toxicity was observed upto $2000 \mathrm{mg} / \mathrm{kg}$ of body weight. The Biological dose of extract Memecylon kollimalayanum dose was selected $200 \mathrm{mg} / \mathrm{kg}$ and $400 \mathrm{mg} / \mathrm{kg}$ in this dose possessed significant antidiabetic activity. In conclusion, in the present study on the ethanolic extract of Memecylon kollimalayanum leaves having antidiabetic activity more over nearest activity of Glibenclamide. This study shows that flavanoids present in this extract may be possibly responsible for the antidiabetic activities. Histopathological studies on isolated pancreas revealed that ethanolic extract of Memecylon kollimalayanum reversed the changes which produced due to diabetes caused by Alloxan. The normal pattern of histology of pancreas was observed. Further pharmacological and biochemical investigation are to be done to find out the active constituent responsible for the antidiabetic activity. However, the future study may also include cataloging, 
standardizing, for quality control and above all developing new drugs/ pharmaceuticals keeping the disease and cost factor in view.

\section{REFERANCE}

1. Njagi JM, Ngugi MP, Kibiti CM, Ngeranwa NJ, Njagi ENM, et al. (2012) Hypoglycemic effects of Caesalpiniavolkensii on alloxan-induced diabetic mice.

2. Babu PV, Liu D, Gilbert ER (2013) Recent advances in understanding the anti-diabetic actions of dietary flavonoids.J Nutr Biochem 24: 1777-1789.

3. Stuart C, Yudofsky, Robert E, Hales (2008) Neuropsychiatry and behavioral neurosciences. (4thEdition) American Psychiatry Publishing, USA 800.

4. Njagi JM, Ngugi MP, Kibiti CM, Ngeranwa J, Njue W, et al. (2015) Hypoglycemic effect of Helichrysumodoratissimum in alloxan induced diabetic mice.

5. World Health Organization (2015) Diabetes Fact Sheet NO.312.

6. Rafeeuddin Md, RaoVN, Shanta Kumar SM, Bheemachari J (2009) Comparative efficacy of four Ayurvedic antidiabetic formulations in alloxan- induced diabetic rabbits. Acta Pharmaceutica Sciencia 51: 33- 38.

7. (2002)Traditional Medicine Strategy 2002-2005. World Health organization.

8. Keter L, Mutiso C (2012) Ethnobotanical studies of medicinal plants used by Traditional Health Practitioners in the management of diabetes in Lower Eastern Province, Kenya. J Ethnopharmacol139: 74-80.

9. Tenpe CR, Yeole PG. Comparative evaluation of antidiabetic activity of some marketed polyherbal formulations in alloxan induced diabetic rats. Int J Pharm Tech Res. 2009 Jan;1(1):43-9.Loomis, W.D., Lile, J.D., Sandstrom, R.P. and Burbott, A.J., 1979. Adsorbent polystyrene as an aid in plant enzyme isolation. Phytochemistry, 18(6), pp.1049-1054.

10. Nimmi, O.S. and George, P., 2012. Preliminary Phytochemical investigation and physicochemical analysis of Polyherbal formulation for antiobesity. Journal of Pharmacy Research Vol, 5(3), pp.1528-1536.

11. Bruce LJ, Daugulis AJ. Solvent selection strategies for extractive biocatalysis. Biotechnology Progress. 1991 Mar 1;7(2):116-24.

12. Audu SA, Mohammed I, Kaita HA. Phytochemical screening of the leaves of Lophira lanceolata (Ochanaceae). Life Science Journal. 2007;4(4):75-9. 
13. Geethu Krishna O, Vishnupriya KV, Thamodaran G, Suresh V, Senthil Kumar N. EVALUATION OF ANTICONVULSANT AND ANXIOLYTIC ACTIVITY OF METHANOLIC EXTRACT OF LEAVES OF SYZYGIUM AQUEUM (BRUM. F).

14. Walum, E., 1998. Acute oral toxicity. Environmental health perspectives, 106(Suppl 2), p.497.

15. O'SUlLIVAN, J.B. and Mahan, C.M., 1964. Criteria for the oral glucose tolerance test in pregnancy. Diabetes, 13, p.278.

16. Bakırel, T., Bakırel, U., Keleş, O.Ü., Ülgen, S.G. and Yardibi, H., 2008. In vivo assessment of antidiabetic and antioxidant activities of rosemary (Rosmarinus officinalis) in alloxandiabetic rabbits. Journal of ethnopharmacology, 116(1), pp.64-73.

17. Kameswararao, B., Kesavulu, M.M. and Apparao, C., 2003. Evaluation of antidiabetic effect of Momordica cymbalaria fruit in alloxan-diabetic rats. Fitoterapia, 74(1-2), pp.713.

18. Kumar, G.P.S., Arulselvan, P., Kumar, D.S. and Subramanian, S.P., 2006. Anti-diabetic activity of fruits of Terminalia chebula on streptozotocin induced diabetic rats. Journal of health science, 52(3), pp.283-291.

19. Dhasarathan, P. and Theriappan, P., 2011. Evaluation of anti-diabetic activity of Strychonous potatorum in alloxan induced diabetic rats. J Med Med Sci, 2(2), pp.670-674

20. Wahi, A.K., Ravi, J., Hemalatha, S. and Singh, P.N., 2002. Anti-diabetic activity of Daemia extensa R. Br. Journal of Natural Remedies,2(1), pp.80-83.

21. Pari, L. and Umamaheswari, J., 2000. Anti hyperglycaemic activity of Musa sapientum flowers: effect on lipid peroxidation in alloxan diabetic rats. Phytotherapy Research: An International Journal Devoted to Pharmacological and Toxicological Evaluation of Natural Product Derivatives, 14(2), pp.136-138.

\section{AJPHR is}

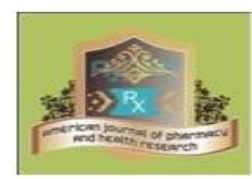

Peer-reviewed

monthly

Rapid publication

Submit your next manuscript at

editor@ajphr.com / editor.ajphr@gmail.com 